\title{
Relaxin deficiency results in increased expression of angiogenesis- and remodelling-related genes in the uterus of early pregnant mice but does not affect endometrial angiogenesis prior to implantation
}

Sarah A. Marshall ${ }^{1}$, Leelee $\mathrm{Ng}^{1}$, Elaine N. Unemori ${ }^{2}$, Jane E. Girling ${ }^{3}$ and Laura J. Parry ${ }^{1 *}$

\begin{abstract}
Background: Extensive uterine adaptations, including angiogenesis, occur prior to implantation in early pregnancy and are potentially regulated by the peptide hormone relaxin. This was investigated in two studies. First, we took a microarray approach using human endometrial stromal (HES) cells treated with relaxin in vitro to screen for target genes. Then we aimed to investigate whether or not relaxin deficiency in mice affected uterine expression of representative genes associated with angiogenesis and uterine remodeling, and also blood vessel proliferation in the pre-implantation mouse endometrium.

Methods: Normal HES cells were isolated and treated with recombinant human relaxin $(10 \mathrm{ng} / \mathrm{ml})$ for $24 \mathrm{~h}$ before microarray analysis. Reverse transcriptase PCR was used to analyze gene expression of relaxin and its receptor (Rxfp 1) in ovaries and uteri; quantitative PCR was used to analyze steroid receptor, angiogenesis and extracellular matrix remodeling genes in the uteri of wild type $(R / n+/+)$ and $R / n-/-$ mice on days $1-4$ of pregnancy.

Immunohistochemistry localized endometrial endothelial cell proliferation and mass spectrometry measured steroid hormones in the plasma.

Results: Microarray analysis identified 63 well-characterized genes that were differentially regulated in HES cells after relaxin treatment. Expression of some of these genes was increased in the uterus of $R / n+/+$ mice by day 4 of pregnancy. There was significantly higher vascular endothelial growth factor A (VegfA), estrogen receptor 1 (Esr1), progesterone receptor (Pgr), Rxfp1, egl-9 family hypoxia-inducible factor 1 (Egln1), hypoxia inducible factor 1 alpha (Hif1a), matrix metalloproteinase 14 (Mmp14) and ankryn repeat domain 37 (Ankrd37) in R/n-/- compared to R/n+/+ mice on day 1. Progesterone receptor expression and plasma progesterone levels were higher in $R / n-/$ - mice compared to $R / n+/+$ mice. However, endometrial angiogenesis was not advanced as pre-implantation endothelial cell proliferation did not differ between genotypes.

(Continued on next page)
\end{abstract}

\footnotetext{
* Correspondence: ljparry@unimelb.edu.au

Jane E. Girling and Laura J. Parry are joint senior authors.

${ }^{1}$ School of BioSciences, The University of Melbourne, Royal Parade, Parkville,

Victoria, Australia

Full list of author information is available at the end of the article
} 
(Continued from previous page)

Conclusions: Relaxin treatment modulates expression of a variety of angiogenesis-related genes in HES cells. However, despite accelerated uterine gene expression of steroid receptor, progesterone and angiogenesis and extracellular matrix remodeling genes in $R / n-/$ - mice, there was no impact on angiogenesis. We conclude that although relaxin deficiency results in phenotypic changes in the pre-implantation uterus, endogenous relaxin does not play a major role in pre-implantation angiogenesis in the mouse uterus.

Keywords: Relaxin, Angiogenesis, Early pregnancy, Uterus, Progesterone

\section{Background}

To start a pregnancy, the endometrium must be in a receptive state for embryo implantation. In women, the endometrium undergoes extensive vascular growth, remodeling, and regression on an approximately monthly basis [1]. During the proliferative phase of the cycle, the endometrium and its associated vasculature undergo a period of rapid growth, with subsequent maturation occurring in the secretory phase [2]. Failure of the endometrium to appropriately remodel and vascularize can result in miscarriage and other pregnancy complications such as fetal growth restriction [3, 4].

Growth, maturation and remodeling of the endometrium and its blood vessels are primarily regulated by the ovarian steroid hormones estrogen and progesterone $[5,6]$. In mice, endometrial endothelial cell proliferation increases prior to embryo implantation in response to increasing plasma progesterone concentrations. Progesterone treatment in ovariectomized mice stimulates angiogenesis; estrogen priming moderates this progesterone-induced endothelial cell proliferation [6]. The peptide hormone relaxin also contributes to remodeling in early pregnancy in primates [7]. Although primarily ovarian in origin, relaxin is also produced by other tissues during pregnancy, including the endometrium, where it is hypothesized to exert paracrine and autocrine uterotrophic effects $[8,9]$. Relaxin treatment of ovariectomized rats and rhesus monkeys primed with estrogen increases uterine weight relative to controls, and also causes increased arteriole number per unit area, dilated blood vessels on the endometrial luminal surface and pronounced endothelial cell proliferation in arterioles and capillaries of the endometrium [9-12]. Implantation bleeding and increased endometrial thickness are observed in relaxin-treated macaque and marmoset monkeys [13, 14], with slightly higher implantation rates following in vitro fertilization and embryo transfer in the macaques [14]. In the context of human physiology, women in a clinical trial for the treatment of scleroderma reported heavier or irregular menstrual bleeding if they were treated with relaxin, possibly due to increased endometrial vascularization $[15,16]$.

Few studies have investigated the direct effects of relaxin on endometrial remodeling and angiogenesis, although relaxin receptors are expressed in the human endometrium and relaxin is known to modify the expression of numerous key regulatory factors [17-20]. For instance, in rhesus macaques relaxin treatment inhibits endometrial estrogen receptor $\alpha(E R \alpha)$, progesterone receptor A (PRA) and progesterone receptor $B$ (PRB) protein levels [9]. Relaxin also stimulates expression and secretion of the pro-angiogenic factor vascular endothelial growth factor (VEGF) in normal human endometrial stromal and glandular epithelial cells in a dose-dependent manner in vitro $[15,21]$. This activation occurs through ER $\alpha$ [22]. Relaxin treatment in macaques has negative impacts on matrix metalloproteinase (MMP) expression causing decreased pro-MMP and an increase in the MMP inhibitor tissue inhibitor of metalloproteinase 1 (TIMP1) [9]. Although these studies provide evidence to support a role for relaxin in uterine vascularization and remodeling in the pre-implantation period, they are limited in their analysis of angiogenesisrelated genes. Therefore, the first aim was to undertake a more comprehensive microarray approach using human endometrial stromal (HES) cells treated with relaxin in vitro to identify candidate angiogenesis-related genes for further investigation.

The relaxin gene knockout $\left(R h^{-/-}\right)$mouse provides a model to investigate endogenous relaxin physiology in the pre-implantation period in vivo; fetal weights in late pregnancy and pup weight at birth are both significantly reduced, suggesting that mice born to $\operatorname{Rln}^{-1}$ mice are growth restricted in utero [23, 24]. Based on the relaxin treatment effects in rodents and rhesus monkeys [9-14], we predicted that this growth restriction could be due to reduced uterine angiogenesis and remodeling in the uterus of $\mathrm{Rln}^{-1-}$ mice. Therefore, the second aim of this study was to investigate whether or not relaxin deficiency affected uterine expression of representative genes associated with angiogenesis and uterine remodeling, and also blood vessel proliferation in the preimplantation endometrium (days 1-4 of pregnancy in mice). This time frame was selected so we could focus on the endometrial changes that occur prior to implantation and independently of any influence from the implanting embryo. As there are no data on paracrine relaxin signaling (relaxin and relaxin receptor, Rxfp1, expression) in the mouse uterus, a third aim was to 
demonstrate that relaxin receptors are present in the endometrium and that there is a uterine source of relaxin in early pregnancy.

\section{Methods}

\section{Animals}

All animal experiments were approved by The University of Melbourne Animal Experimental Ethics Committee (AEEC \#0911478.1) and conducted in accordance with the Australian Code of Practice and the National Health and Medical Research Council. This study used wild type $\left(R l n^{+/+}\right)$and $R l^{-/-}$mice. Homologous recombination in embryonic stem cells was used to disrupt the relaxin gene by deleting a region essential for biological activity and replacing it with the neomycin transferase gene [25]. $\mathrm{Rln}^{-1-}$ mice were then backcrossed to a C57/BLK6J background and the F14 generation relocated to the School of BioSciences. Genotypes were confirmed by PCR analysis of genomic DNA from ear clips as previously described [25]. Mice were maintained on an automated time cycle of $12 \mathrm{~h}$ light/dark at $20{ }^{\circ} \mathrm{C}$, with laboratory chow (Barastock, Pakenham,VIC, Australia) and water available ad libitum.

\section{Identification of RXFP1 in the endometrium of $R \times f p 1^{T G}$ mice}

Uterine tissues from non-pregnant transgenic mice with a modified $R x f p 1$ gene $(n=3)$ were kindly provided by Prof AI Agoulnik (Florida International University, Miami, FL, USA). The modification is a $4 \mathrm{~kb}$ fragment containing parts of exons 15 and 17 that was ligated into a SalI site of the pNTR-LacZ/PGKneo/loxP vector as described by Kamat et al [26]. During homologous integration, the targeting vector was inserted into exon 17 and created a duplication of the $4 \mathrm{~kb}$ genomic fragment. Uterine tissues were dissected from $R x f p 1^{T G}$ mice after anesthetic overdose and were fixed in $2 \%$ paraformaldehyde in $1 \mathrm{X}$ phosphate buffered saline $/ \mathrm{MgCl}_{2}$ for 30 mins at RT. Tissues were then embedded in Tissue-Tek OCT compound (Sakura Finetechnical Co. Ltd), and cryosections were cut at $10 \mu \mathrm{m}$ and mounted on Superfrost slides. For histological analysis of LacZ expression, tissues sections were processed for X-gal staining using the LacZ Detection Kit for Tissues (InvivoGen) according to the manufacturer's instructions. Nuclei were then counterstained with $0.1 \%$ nuclear fast red and mounted in aqueous mounting medium. Control tissues were obtained from wild type littermates.

\section{Effects of relaxin treatment on human endometrial stromal cells in vitro}

HES cells were isolated from a collagenase-treated uterus of a pre-menopausal woman who had a hysterectomy for reasons other than uterine disease, with informed consent and approval from the institutional review board $[15,27]$.
Stromal cells obtained from a normal uterus were cultured in $75 \mathrm{~mm}^{2}$ flasks, and fed every two days with DMEM:F12 medium plus $10 \%$ newborn calf serum and $2 \mathrm{mM}$ L-glutamate. These cells have previously been shown to possess high affinity relaxin binding sites [15] and to produce cAMP in response to relaxin [27]. Once confluent, the cells were washed with phosphate buffered saline (PBS) and treated in serum-free DMEM:F12 medium with either vehicle alone or with recombinant human relaxin (rhRLX) (Connetics Corporation, Palo Alto, CA, USA) $(10 \mathrm{ng} / \mathrm{ml})$ for $24 \mathrm{~h}$. This concentration and duration was shown to be bioactive in a previous study [15]. Total RNA was isolated using Trizol (Invitrogen) according to manufacturer's instructions. Total RNA from 8 HES cell cultures treated with vehicle or with rhRLX were pooled to yield $100 \mu \mathrm{g}$ RNA each. This was sent to Incyte Genomics (Palo Alto) for extraction of PolyA-RNA and subsequent microarray analysis [28]. Briefly, 600 ng of polyA-RNA of each sample was used for reverse transcription and attachment of the appropriate cyanine (Cy) dye. The Cy3- and Cy5-labelled probes were then mixed, and simultaneously hybridized to a single cDNA microarray. Following incubation, the array was washed in 3 consecutive washes of decreasing ionic strength, and scanned in both $\mathrm{Cy} 3$ and $\mathrm{Cy} 5$ channels using GenePix scanners (Foster City). Incyte GEMtools software was used for image analysis. Background-subtracted element signals are used to calculate Cy3:Cy5 ratios. Default criteria in GEMtools analysis are that the signal-to- background ratio $>2.5$ for each element, and that the area for which pixel values are counted is at least $40 \%$ of the element for both signals. The ratio of fluorescent intensities from the two dyes were used to assess relative transcript abundance in the two RNA samples. The minimum detectable fold change for differential expression, according to evaluation of the performance of the Incyte array, is 1.4-fold [29], i.e. expression in mRNA from rhRLX-treated cells 1.4-fold higher than in vehicle-treated cells, or vice versa.

\section{Effects of relaxin deficiency in early pregnancy}

In Study $1, R l n^{+/+}$mice were studied on days $1,2,3$ and 4 of pregnancy to assess changes in gene expression in the wild type mice ( $n=8 /$ genotype/day). Based on data from Study 1, we then chose to examine pre-implantation phenotypes in $\mathrm{Rln}^{+/+}$and $\mathrm{Rln}^{-/-}$mice only on days 1 and 4 of pregnancy (Study 2, $n=8 /$ genotype/day). In Study 3, gene expression alone was examined in an additional group of mice on day 6 of pregnancy ( $n=7 /$ genotype) to examine if phenotypes persisted after implantation (Additional file 1: Figure S1). Female mice aged 2-4 months were housed with a stud male of matched genotype overnight and then checked for mating plugs the following morning. The presence of a mating plug was an indication 
of successful mating and was considered day 1 of pregnancy. Four hours prior to tissue collection, mice received a $500 \mu \mathrm{l}$ i.p. injection of bromodeoxyuridine (BrdU; $2 \mathrm{mg} /$ $\mathrm{ml}$, Sigma-Aldrich Pty Ltd), enabling later visualization of proliferating cells by immunohistochemistry. After isofluorane anesthesia, blood was collected by cardiac puncture and the plasma stored at $-80{ }^{\circ} \mathrm{C}$. After cervical dislocation, the uterine tissues were removed with half fixed in $10 \%$ neutral buffered formalin overnight before processing for paraffin sections, and the other half stored at $-80{ }^{\circ} \mathrm{C}$ for gene expression analysis.

\section{Analysis of gene expression}

Total RNA was isolated from whole uteri using Trizol reagent (Invitrogen) according to the manufacturer's instructions. The concentration of RNA was determined using a NanoDrop ND100 Spectrophotometer (NanoDrop Technologies Inc) with A260:A280 absorbance ratios of $>2.0$ indicating sufficiently pure RNA for PCR analysis. First strand cDNA synthesis used $1 \mu \mathrm{g}$ total RNA in a $20 \mu \mathrm{L}$ reaction, using random hexamers (50 ng/ $\mu \mathrm{L}$ ), $10 \mathrm{mM} \mathrm{dNTP}$ and $200 \mathrm{U}$ SuperScript III (Invitrogen). First-strand cDNA synthesis for all samples were performed simultaneously at $25{ }^{\circ} \mathrm{C}$ for $10 \mathrm{~min}, 50{ }^{\circ} \mathrm{C}$ for $50 \mathrm{~min}$ and $85{ }^{\circ} \mathrm{C}$ for $5 \mathrm{~min}$. Quantitative reverse-transcription polymerase chain reaction (quantitative PCR) was performed to assess the relative expression of relaxin $(R l n)$ and its receptor $R x f p 1$ and key genes chosen to represent angiogenesis (total VEGFA (VegfA), VEGF receptor 2 (Vegfr 2)), steroid receptors (estrogen receptor (ER)- $\alpha$ (Esr1), ER- $\beta$ (Esr2), progesterone receptor $(P g r)$ ), tissue remodeling (matrix metalloproteinase 14 (Mmp14), Timp3)), and other key genes identified in our microarray analysis (ankryn repeat domain 37 (Ankrd37), egl-9 family hypoxia-inducible factor $1(E g \ln 1)$, hepatocyte growth factor $(H g f)$, hypoxia inducible factor $1 \alpha($ Hifl $\alpha)$ ). In addition to these genes investigated pre-implantation, interleukin $1 \beta(I l 1 \beta)$ was also investigated post-implantation (Additional file 2: Figure S2). Forward and reverse primers and 6-carboxy fluorescein (FAM)-labeled TaqMan probes specific for mouse genes were designed to span an intron/exon junction (Biosearch Technologies, Inc). Primer sequences are shown in Additional file 3: Table S1. All quantitative PCR reactions for each gene were performed on one plate, in $10 \mu \mathrm{l}$ or $20 \mu \mathrm{l}$ 96-well reactions containing SensiFAST Probe Lo-Rox (BioRad) and performed in the ViiA ${ }^{\mathrm{s}} 7$ Real-Time PCR System (Life Technologies). Recent data suggest that glyceraldehyde 3-phosphate dehydrogenase (Gapdh) and $18 \mathrm{~s}$ ribosomal RNA (18 s) expression are upregulated in the rodent uterus in response to progesterone and estrogen [30, 31 ]. The same pattern of $18 s$ mRNA expression was observed in this study so we investigated peptidylprolyl isomerase A (Ppia), succinate dehydrogenase complex, subunit A (Sdha) and TATA box binding protein $(T b p)$ as reference genes; however, these were also significantly increased from days 1 to 4 of pregnancy (Additional file 2: Figure S2). Therefore we used the mean $C_{T}$ value of the $R \ln ^{+/+}$mice on day 1 of pregnancy as the internal calibrator and subtracted this from the mean gene of interest triplicate $C_{\mathrm{T}}$ value $\left(\right.$ Ratio $_{\text {(test/calibrator) }}=2^{\Delta \mathrm{CT}}$, where $\Delta C_{\mathrm{T}}=$ $\left.\mathrm{C}_{\mathrm{T} \text { (calibrator) }}-\mathrm{C}_{\mathrm{T}(\text { test })}\right)$ as has been described previously $[30,32]$. These "normalized" data $\left(\Delta C_{T}\right)$ were presented as fold induction relative to day 1 of pregnancy in the $\mathrm{Rln}^{+/+}$mice. The mean $\mathrm{C}_{\mathrm{T}}$ values and range $\mathrm{C}_{\mathrm{T}}$ values for each gene are presented in Additional file 3: Table S2.

The presence or absence of relaxin $(R \ln )$ and $R x f p 1$ gene transcripts in the uterus and ovaries were assessed by reverse transcriptase polymerase chain reaction (RTPCR) in the GeneAmp PCR system 2700 (Applied Biosystems). Reaction mixes consisted of GoTaq Green (Promega), mouse-specific oligonucleotide primers (100 ng/ $\mu \mathrm{l})$ designed to span an intron/exon junction (Additional file 3: Table S3) and $1 \mu \mathrm{l}$ cDNA. Ovary RNA was extracted as described above.

\section{Immunohistochemistry}

As the study focused on pre-implantation vascular remodeling, we used immunohistochemistry to examine endometrial endothelial cell proliferation as a marker of endometrial angiogenesis. We used a dual immunohistochemistry protocol with antibodies against CD31 (panendothelial cell marker) and BrdU (labels proliferating cells). After dewaxing and rehydration, sections $(5 \mu \mathrm{m})$ were incubated with $0.1 \%(1 \mathrm{mg} / \mathrm{ml})$ pepsin in $3 \%$ acetic acid for $10 \mathrm{~min}$ at $37{ }^{\circ} \mathrm{C}$, followed by serum free protein block (Dako) for $15 \mathrm{~min}$ to prevent non-specific binding. Sections were incubated with rat monoclonal anti-mouse CD31 $(5 \mathrm{mg} / \mathrm{ml}$ in $1 \%$ bovine serum albumin in PBS (BSA/PBS) (BD PharMingen)) overnight at $4{ }^{\circ} \mathrm{C}$. Sections were then incubated for $1 \mathrm{~h}$ at room temperature in biotinylated goat anti-rat IgG (1:200 in $1 \%$ BSA/PBS, Chemicon), followed by incubation in alkaline phosphatase conjugated streptavidin (Dako) for 15 min. CD31-positive immunostaining was visualized using the vector blue alkaline phosphatase chromagen (10 min, Vector Laboratories). Sections were then incubated in $0.1 \mathrm{M} \mathrm{HCl}$ for $45 \mathrm{~min}$ at room temperature, followed by a further incubation $3 \% \mathrm{H}_{2} \mathrm{O}_{2}$ in PBS for $10 \mathrm{~min}$ at room temperature to quench endogenous peroxidase. Serum free protein block was applied for a further $15 \mathrm{~min}$. Sections were incubated for $1 \mathrm{~h}$ at room temperature in monoclonal sheep anti-BrdU $(8 \mu \mathrm{g} / \mathrm{ml}$ in $1 \%$ BSA/PBS, Abcam). This was followed by a further incubation for $1 \mathrm{~h}$ at room temperature in donkey antisheep IgG $(4 \mu \mathrm{g} / \mathrm{mL}$ in $1 \%$ BSA/PBS, Jackson Immuno 
Research Laboratories). Sections were then incubated in streptavidin horseradish peroxidase (Dako) for $15 \mathrm{~min}$, followed by $5 \mathrm{~min}$ in DAB chromagen $(3,30$ diaminobenzidine, Sigma-Aldrich) to visualize BrdU immunostaining. Each slide contained a negative isotope matched control section that was prepared by replacing the CD31 primary antibody with rat IgG2a (BD Biosciences) and the BrdU primary antibody with sheep IgG (Sigma-Aldrich) at the same concentrations as that of the primary antibodies. For the main analysis, we analyzed one section per uterus ( $n=7$ /group) taken from the mid-point between the cervix and ovaries. The number of proliferative endothelial cells and the number of blood vessel profiles present in the endometrial tissue on each section were counted. Data are presented as the proportion of vessel profiles

a

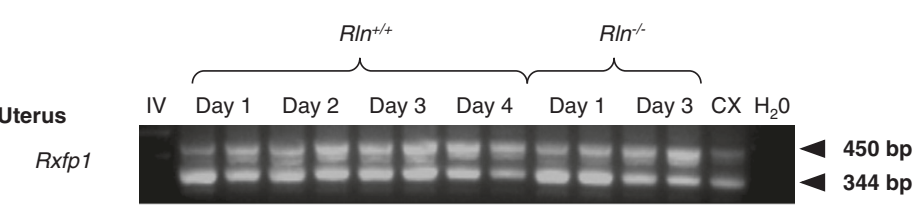

b

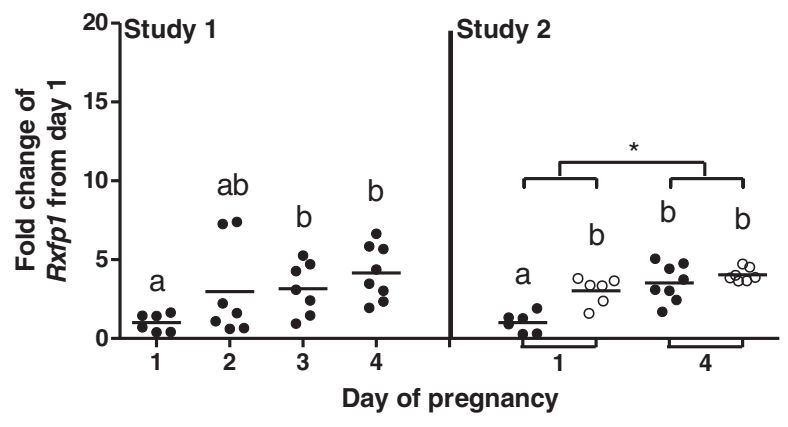

- $R / n^{+/+}$

- $R / n^{-1-}$

C
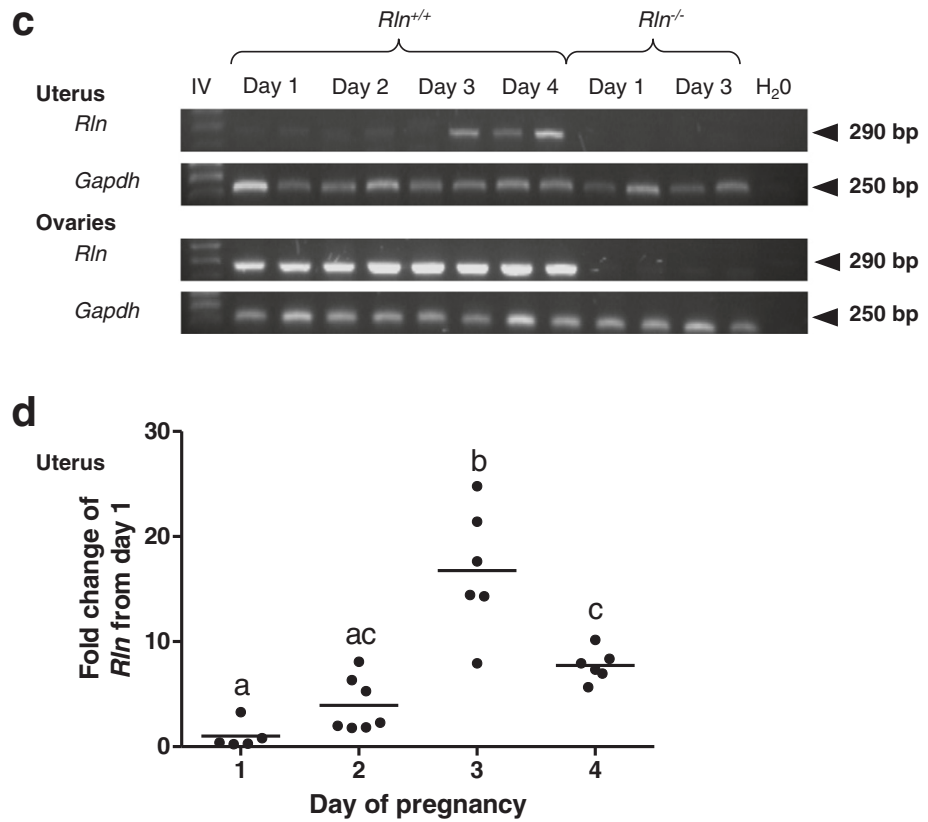

Fig. 1 a Reverse transcriptase PCR (RT-PCR) expression of $R x f p 1$ in the uterus of wild type $\left(R / n^{+/+}\right)$and relaxin deficient $\left(R / n^{-/}\right)$mice in early pregnancy. The positive control for Rxfp1 was the cervix (CX). Note the two RXFP1 isoforms. The negative control was water $\left(\mathrm{H}_{2} \mathrm{O}\right)$. IV $=\mathrm{Hyperladder}$ OV. b Quantitative PCR analysis of Rxfp 1 mRNA in the uterus of $R / n^{+/+}$mice from days 1 to 4 of pregnancy (Study 1), and in $R / n^{+/+}$and $R / n^{-/-}$mice on days 1 and 4 (Study 2) (n=6-8). c RT-PCR expression of relaxin (RIn) and Gapdh in the uterus and ovaries of $R / n^{+/+}$and $R / n^{-1-}$ mice in early pregnancy. d Quantitative PCR analysis of RIn mRNA in the uterus of $R / n^{+/+}$mice from days 1 to 4 of pregnancy. Expression is shown as the fold change compared with the mean gene expression in $R / n^{+/+}$mice on day 1 of pregnancy. Horizontal bars indicate mean values. Groups within each study that do not share a letter are significantly different from one another, ${ }^{*}$ denotes a significant difference between day 1 and 4 of pregnancy in study 2 , significance is $p<0.05$ 
containing one or more proliferating endothelial cells, and as the number of proliferating endothelial cells per $\mathrm{mm}^{2}$ (identified using a $\times 40$ objective lens).

\section{Steroid analysis}

Plasma progesterone and corticosterone concentrations were measured by triple quadrupole mass spectrometry (Eric Thorstensen, Liggins Institute, University of Auckland, Auckland, New Zealand). Estrogen could not be measured as there was insufficient plasma for accurate detection. An internal standard solution $\left(60 \mathrm{ng} \mathrm{mL} \mathrm{L}^{-1}\right.$ corticosterone- $\mathrm{d} 8$ and $0.2 \mathrm{ng} \mathrm{mL}^{-1}$ estradiol- $\mathrm{d} 3$ in water) was added to each plasma sample $(100 \mu \mathrm{L}$ standard to $200 \mu \mathrm{L}$ plasma). Steroids were then extracted using $1 \mathrm{~mL}$ of ethyl acetate (Merck). After removal of the organic supernatant to a clean tube, samples were dried by vacuum concentration (Savant SC250EXP, Thermo Scientific), resuspended in $60 \mu \mathrm{L}$ of mobile phase $(45 \%$ methanol and $55 \%$ water) and transferred to HPLC injector vials. Samples $(12 \mu \mathrm{L})$ were injected onto an HPLC mass spectrometer system consisting of an Accela MS pump and autosampler followed by an Ion Max APCI source on a Finnigan TSQ Quantum Ultra AM triple quadrupole mass spectrometer all controlled by Finnigan Xcalibur software (Thermo Electron Corporation). The mobile phase was a gradient of methanol and water, flowing at $400 \mu \mathrm{L} \cdot \mathrm{min}^{-1}$ through a Hypersil Gold $1.9 \mu \mathrm{m} \mathrm{C} 1850 \times 2.0 \mathrm{~mm}$ column at $40{ }^{\circ} \mathrm{C}$ (Thermo Fisher Scientific). Retention time was $6.2 \mathrm{~min}$ for progesterone and $2.3 \mathrm{~min}$ for corticosterone. Ionization was in positive mode for progesterone, Q2 had 1.2 mTorr of argon. The mass transitions followed were: progesterone $315.5 \rightarrow 109.2$ at $22 \mathrm{~V}$ and corticosterone $347.2 \rightarrow 121.0$ at $27 \mathrm{~V}$.

\section{Statistical analysis}

Proliferating endothelial cell number and circulating steroid hormone concentrations were assessed by two-way ANOVA (genotype $\mathrm{v}$ day of pregnancy) and Tukey posthoc tests (SPSS Inc.). Changes in gene expression during early pregnancy in the $\mathrm{Rln}^{+/+}$mice were assessed by oneway ANOVA (day of pregnancy) and Tukey post-hoc tests. Two-way ANOVA with genotype and day of pregnancy as main effects assessed any interaction between genotype and day of pregnancy in the $R \mathrm{Rn}^{+/+}$and $\mathrm{Rln}^{-/-}$mice followed by Tukey post-hoc tests to compare means of all groups. T-tests were used to examine gene expression differences between $\mathrm{Rln}^{+/+}$and $\mathrm{Rln}^{-/}$mice on day 6 of pregnancy. If not normally distributed, raw data were log transformed and non-parametric analysis was performed using MannWhitney with Bonferroni correction. All figures are graphed using the untransformed fold change data.

\section{Results}

\section{Relaxin signaling in early pregnancy}

Reverse transcriptase PCR confirmed the presence of two gene transcripts for $R x f p 1$ representing both isoforms in the uterus of both $\mathrm{Rln}^{+/+}$and $\mathrm{Rln}^{-1-}$ mice in early pregnancy (Fig. 1a) (raw $C_{T}$ values in Additional file 3: Table S2). There was a significant $(p=0.006)$ increase in $R x f p 1$ mRNA in $R n^{+/+}$mice on days 3 and 4 of pregnancy compared with day 1 (Fig. 1b). A

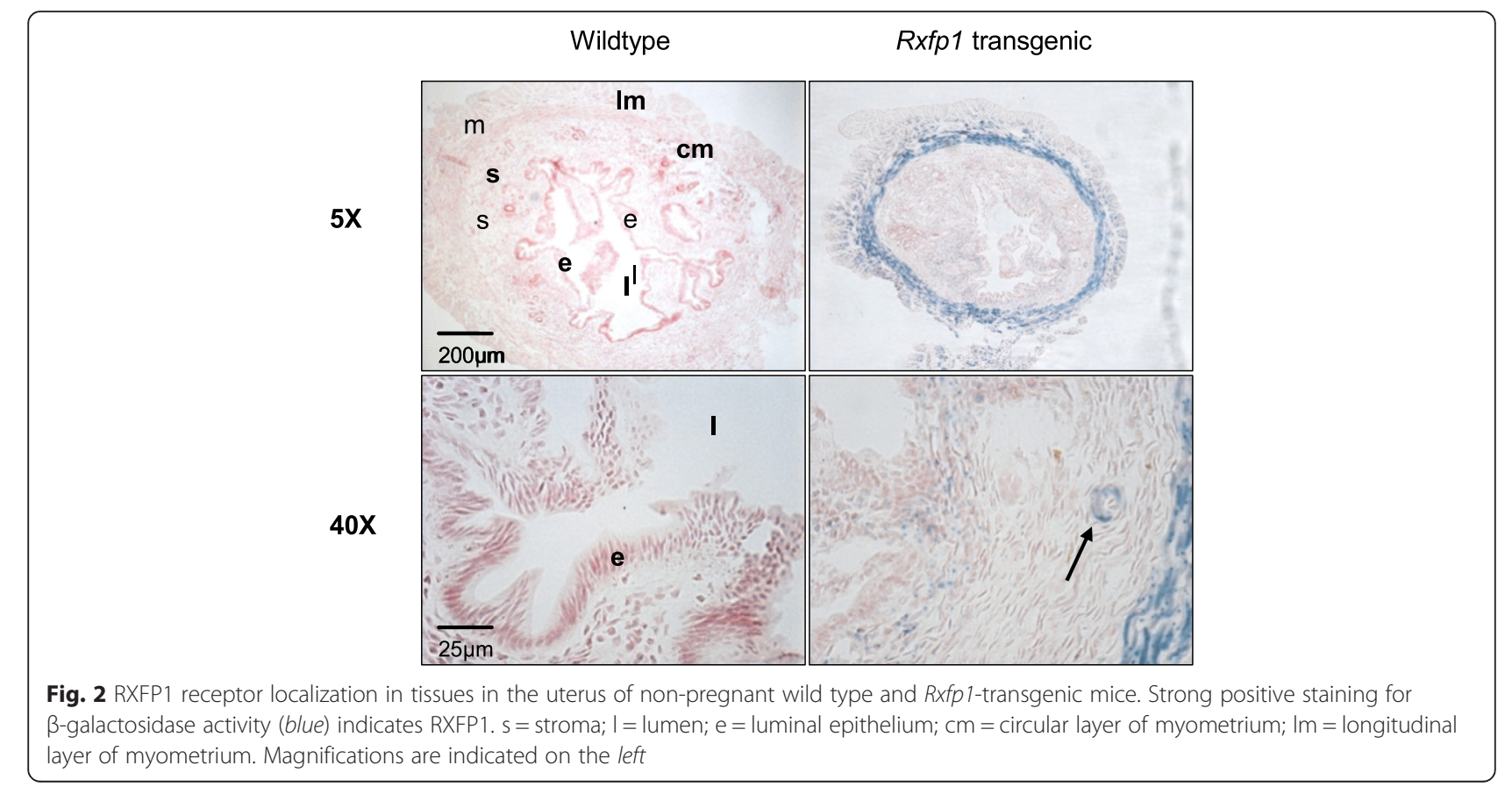


Table 1 Selected genes modulated by human recombinant relaxin treatment of human endometrial stromal cells in vitro

\begin{tabular}{|c|c|c|c|}
\hline Category & Gene & Accession number & Fold-change \\
\hline \multirow[t]{6}{*}{ Angiogenesis related } & Tissue inhibitor of metalloproteinase-3 & NM_000362 & +1.9 \\
\hline & Hypoxia-inducible factor 1, alpha subunit & NM_001530 & +1.5 \\
\hline & Hepatocyte growth factor & NM_000601 & +1.5 \\
\hline & Angiogenin & NM_001145 & +1.4 \\
\hline & Vascular endothelial growth factor A & NM_001025366 & +1.2 \\
\hline & Vascular endothelial growth factor D & NM_004469 & -0.3 \\
\hline Angiogenesis inhibitors & CD36 & NM_001001548 & -0.3 \\
\hline \multirow[t]{2}{*}{ Hemostasis/menses correlated } & Matrix metalloproteinase-7 & NM_002423 & -0.4 \\
\hline & Tissue plasminogen activator & NM_000930 & -0.3 \\
\hline \multirow[t]{2}{*}{ Secretory phase expression } & Interleukin 1 receptor-like 1 & NM_003856 & +1.5 \\
\hline & CD44 & NM_000610 & -0.3 \\
\hline \multirow[t]{2}{*}{ Proliferative phase expression } & Tenascin C & NM_002160 & -0.4 \\
\hline & Androgen receptor & NM_000044 & -0.3 \\
\hline \multirow[t]{3}{*}{ Renin-angiotensin system } & Renin & NM_000537 & +1.4 \\
\hline & Angiotensin I| receptor 1 & NM_000685 & +1.4 \\
\hline & Angiotensin II receptor 2 & NM_000686 & -0.3 \\
\hline \multirow[t]{5}{*}{ Growth factors/cytokines } & Insulin-like growth factor binding protein 4 & NM_001552 & +1.4 \\
\hline & Insulin-like growth factor 1 & NM_001111284 & +1.4 \\
\hline & Osteoclast stimulating factor 1 & NM_012383 & +1.4 \\
\hline & Amphiregulin & NM_001657 & +1.4 \\
\hline & Connective tissue growth factor & NM_001901 & -0.3 \\
\hline \multirow[t]{10}{*}{ Structural proteins } & Dystrophin & NM_004011 & +1.6 \\
\hline & Claudin 10 & NM_006984 & +1.5 \\
\hline & Tetraspan 3 & NM_005724 & +1.4 \\
\hline & Myosin X & NM_012334 & +1.4 \\
\hline & Contactin 1 & NM_001843 & +1.4 \\
\hline & Keratocan & NM_007035 & -0.5 \\
\hline & Matrin 3 & NM_199189 & -0.3 \\
\hline & Sorcin & NM_003130 & -0.3 \\
\hline & Cadherin-2 & NM_001792 & -0.3 \\
\hline & Tight junction protein 1 & NM_003257 & -0.3 \\
\hline \multirow[t]{2}{*}{ Extracellular matrix } & Fibronectin & NM_212482 & -0.3 \\
\hline & Nidogen (entactin) & NM_002805 & -0.3 \\
\hline \multirow[t]{4}{*}{ Metabolism } & Glycerol kinase & NM_203391 & +2.0 \\
\hline & Acyl-Coenzyme A dehydrogenase & NM_000016 & +1.6 \\
\hline & Ceruloplasm & NM_000096 & +1.4 \\
\hline & Transferrin & NM_001063 & +1.4 \\
\hline \multirow[t]{5}{*}{ Enzymes/inhibitors } & Heparin cofactor II & NM_000185 & +1.8 \\
\hline & Serine protease inhibitor & NM_001127698 & +1.5 \\
\hline & Carboxypeptidase B2 & NM_001872 & +1.5 \\
\hline & Aminoacylase 1 & NM_000666 & +1.4 \\
\hline & Cathepsin B & NM_001908 & -0.3 \\
\hline
\end{tabular}


Table 1 Selected genes modulated by human recombinant relaxin treatment of human endometrial stromal cells in vitro (Continued)

\begin{tabular}{|c|c|c|c|}
\hline \multirow[t]{4}{*}{ Transcription factors } & Kruppel-like factor-1 & NM_006563 & +1.5 \\
\hline & Eukaryotic translation termination factor 1 & NM_004730 & +1.5 \\
\hline & Eukaryotic translation initiation factor 3 & NM_003758 & +1.5 \\
\hline & Transactivator jun-B & NM_002229 & +1.4 \\
\hline \multirow[t]{7}{*}{ Protein kinases } & Mitogen-activated protein kinase 4 & NM_002747 & +1.5 \\
\hline & Protein kinase, CAMP-dependent regulatory & NM_002734 & +1.4 \\
\hline & Calcium/calmodium protein kinase I & NM_003656 & +1.4 \\
\hline & Calcium/calmodium protein kinase II & NM_172127 & +1.4 \\
\hline & Protein kinase, cAMP-dependent catalytic & NM_002731 & -0.4 \\
\hline & Mitogen-activated protein kinase 1 & NM_002745 & -0.3 \\
\hline & Cyclin G1 & NM_004060 & -0.3 \\
\hline \multirow[t]{5}{*}{ Receptors } & Retinal G-protein coupled receptor & NM_002921 & +1.5 \\
\hline & Hyaluronan-mediated motility receptor & NM_001142556 & +1.4 \\
\hline & Vasoactive intestinal peptide receptor 2 & NM_003382 & +1.4 \\
\hline & Activin A receptor IB & NM_004302 & -0.3 \\
\hline & Chemokine receptor 1 & NM_001295 & -0.3 \\
\hline \multirow[t]{6}{*}{ Others } & Lacrimal proline-rich protein & NM_007244 & +1.6 \\
\hline & Trefoil factor-1 & NM_003225 & +1.6 \\
\hline & Amyloid precursor protein binding protein-2 & NM_006380 & +1.5 \\
\hline & Neurogenic differentiation 1 & NM_002500 & +1.5 \\
\hline & Annexin A3 & NM_005139 & +1.5 \\
\hline & Basonuclin 1 & NM_001717 & -0.5 \\
\hline
\end{tabular}

comparison between genotypes revealed a significant $(p=$ 0.003 ) increase in $R x f p 1$ expression on day 1 in $\mathrm{Rln}^{-1-}$ mice compared to day 1 in $R \ln ^{+/+}$mice but expression on day 4 of pregnancy was similar between $R l n^{+/+}$and $\mathrm{Rln}^{-/-}$mice (Fig. 1b). $R \ln$ mRNA was detected at all stages in the ovaries of the wild type mice (Fig. 1c). $R \ln$ mRNA was also detected in whole uterus, with significantly increased expression on days 3 and 4 of pregnancy relative to day 1 $(p<0.05)$ (Fig. 1c and d).

Strong positive staining for $R x f p 1$-specific $\beta$-galactosidase activity was identified in the myometrium of $R x f p 1^{T G}$ mice, particularly in the inner circular muscle layer (Fig. 2). Upon closer examination of the endometrium, positive staining for $R x f p 1$-specific $\beta$-galactosidase activity was seen in the stroma towards the luminal epithelium. The negative control used in this study was the uterus of a wild type mouse, which showed no endogenous or background $\beta$ galactosidase activity (Fig. 2). This confirmed that the $\beta$-galactosidase activity observed in the $R x f p 1^{T G}$ mouse uterus was specific and represents localization of $R x f p 1$.

Effects of relaxin on angiogenesis-related gene expression in human endometrial stromal cells

A total of 321 genes were upregulated (by 1.4-fold or more) in HES cells incubated with rhRLX for $24 \mathrm{~h}$, whereas 203 genes were down-regulated by at least $30 \%$. 64 well characterized genes increased with relaxin treatment (Table 1), of which glycerol kinase showed the largest increase (2-fold). A number of genes whose expression is associated with regulation of angiogenesis were among those modulated by rhRLX. Timp3 (1.9fold), Hgf, (1.5-fold) Hif1 $\alpha$ (1.5-fold) and angiogenin (1.4-fold) were increased. The expression of VEGF was analyzed as 1.2-fold higher in relaxin-treated cells, within the noise of the assay. In contrast, VEGF-D and CD36 were decreased by $30 \%$. CD36 thought to be an inhibitor of angiogenesis [33] was down-regulated by $30 \%$ after rhRLX treatment.

\section{Gene expression in the uterus of early pregnant $\mathrm{RIn}^{+/+}$ and $\mathrm{RIn}^{-/-}$mice}

Consistent with prior studies [34], there was a modest increase in VegfA on day 4 of pregnancy compared with day 1 in the wild type mice in study $2(p=0.012)$ (Fig. 3a). A comparison between genotypes demonstrated a significant $(p=0.026)$ increase in VegfA on day 1 of pregnancy in the $\mathrm{Rln}^{-1-}$ mice compared with the same time point in $R l n^{+/+}$mice. Similarly, there was a significant (Day 3: $p=0.006$; Day 4: $p=0.002$ ) increase in Vegfr 2 on days 3 and 4 of pregnancy in $R l n^{+/+}$mice 


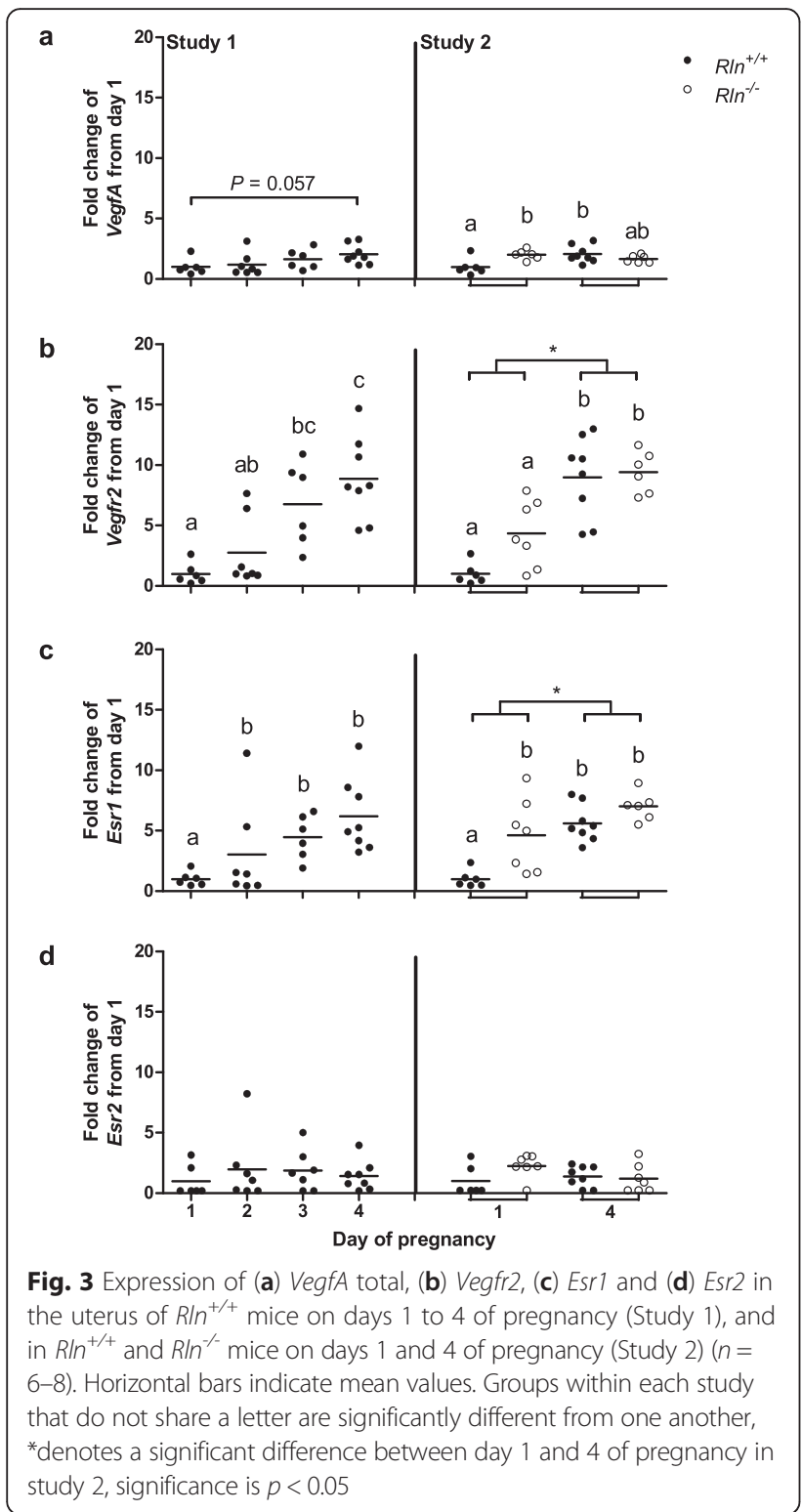

compared with day 1 but there was no effect of genotype (Fig. 3b).

Because relaxin is known to modulate steroid receptor expression [9], Esr1 and Esr2 transcripts were examined (Pgr was also examined, see below). Esr1 but not Esr2 was significantly (Day 2: $p=0.01$; Day 3: $p=0.002$; Day 4: $p=0.004$ ) increased in $\operatorname{Rln}^{+/+}$mice on days 2,3 and 4 of pregnancy. Only Esrl expression was significantly (pregnancy: $p \leq 0.001$; genotype: $p=0.002$ ) affected by both pregnancy and genotype (Fig. $3 \mathrm{c}$ and $\mathrm{d}$ ).

Mmp14 and Timp3 were also significantly (Mmp14: Day 3: $p=0.012$; Day 4: $p=0.003$, Timp3: Day 3: $p=$ 0.019; Day 4: $p=0.004)$ upregulated on days 3 and 4 compared with day 1 in pregnant $R \operatorname{Rn}^{+/+}$mice (Fig. 4). Interestingly, Mmp14 was significantly $(p=0.001)$ higher
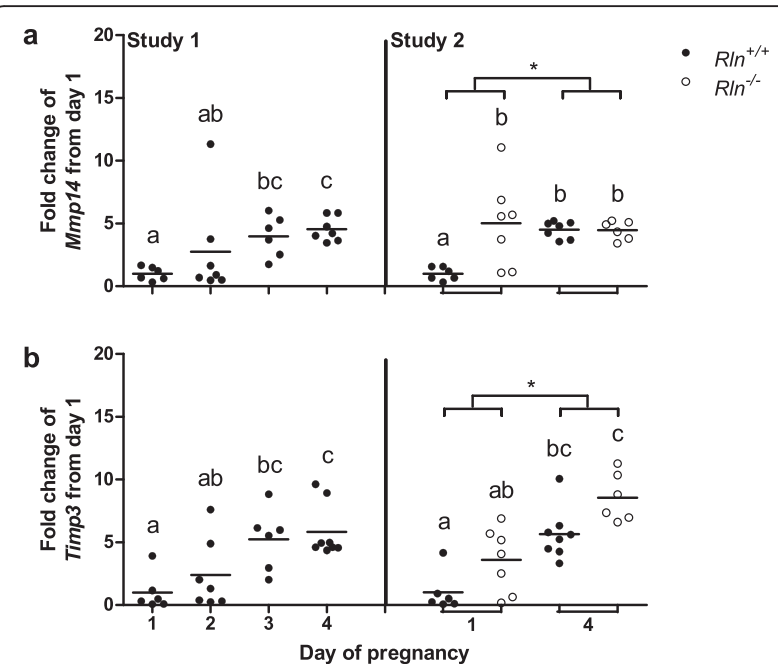

Fig. 4 Expression of extracellular matrix remodeling genes (a) Mmp14 and (b) Timp3 in the uterus of $R / n^{+/+}$mice from days 1 to 4 of pregnancy (Study 1 ) and in $R / n^{+/+}$and $R / n^{-/}$mice on days 1 and 4 of pregnancy (Study 2) $(n=6-8)$. Horizontal bars indicate mean values. Groups within each study that do not share a letter are significantly different from one another, ${ }^{*}$ denotes a significant difference between day 1 and 4 of pregnancy in study 2 , significance is $p<0.05$

in $\mathrm{Rln}^{-1-}$ mice on day 1 of pregnancy compared with the $R \mathrm{Rn}^{+/+}$counterpart, whereas there was no significant effect of genotype on Timp3 expression. However Timp3 was significantly (pregnancy: $p \leq 0.001$ ) higher on day 4 of pregnancy compared with day 1 in both genotypes in study 2.

Based on the data from the microarray study of HES cells (Table 1), we analyzed four other genes that were altered by relaxin treatment. In wild type mice, there was no significant increase in Ankrd37 from days 1 to day 4 of pregnancy (Fig. 5a). A comparison of genotypes demonstrated a significant $(p=0.011)$ increase in Ankrd37 on day 1 in the $R \ln { }^{-/-}$mice compared with $R l^{+/+}$. $E g \ln 1$ was significantly $(p=0.015)$ upregulated on day 4 of pregnancy in $\mathrm{Rln}^{+/+}$mice compared to days 1 and 2 (Fig. $5 \mathrm{~b}$ ). There was also a significant $(p \leq 0.001)$ difference between the genotypes on day 1 . Both $H g f$ and $H i f 1 \alpha$ were significantly $(p<0.05)$ increased on days 3 and 4 in the wild type mice compared to day 1 of pregnancy (Fig. 5c and d). Hifl $\alpha$ expression was significantly $(p=0.008)$ upregulated in the $\mathrm{Rln}^{-/}$mice on day 1 compared with $\operatorname{Rln}^{+/+}$but there was no difference in $H g f$ between the genotypes.

We also examined expression of the genes noted above in uteri from day 6 pregnant mice, but no significant differences were observed between $R h^{+/+}$and $R l n^{-/-}$mice (Additional file 1: Figure S1).

\section{Pre-implantation endometrial angiogenesis}

Endothelial cell proliferation occurred in the endometrium on day 4 but not day 1 of pregnancy in wild type 


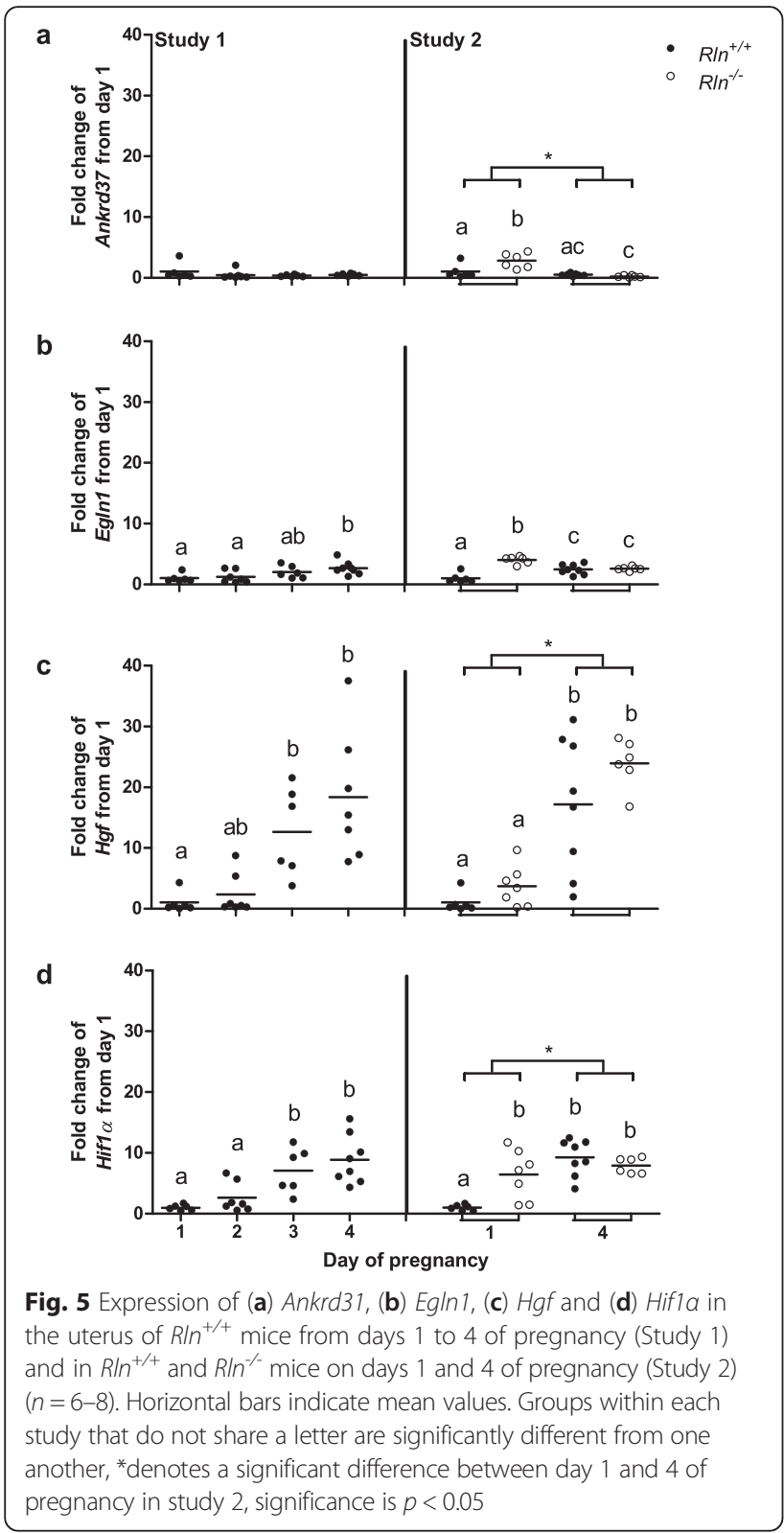

mice, consistent with a previous report [6]. Proliferation in the $\mathrm{Rln}^{-/-}$mice also occurred on day 4 (Fig. 6). However, there was no significant difference in the percentage of vessel profiles containing proliferating endothelial cells or the number of proliferating endothelial cells in the endometrium per $\mathrm{mm}^{2}$ between the genotypes. Additionally, there was no difference in the number of vessels per $\mathrm{mm}^{2}$ (data not shown).

\section{Plasma progesterone and corticosterone concentrations}

As seen in previous studies [6], there was a significant $(p \leq 0.001)$ effect of day of pregnancy on circulating progesterone levels in the wild type and relaxin deficient mice from day 1 to day 4 of pregnancy (Fig. 7a). Plasma progesterone concentrations were significantly ( $p=$ 0.013) different between the two genotypes on day 4 , with an increase in progesterone in the $\mathrm{Rln}^{-1-}$ mice relative to the $\mathrm{Rln}^{+/+}$mice. There was a significant (Day 1: $p=0.017$; Day 4: $p=0.005$ ) increase in Pgr in $R^{-1} n^{-1}$ mice compared to $R \ln ^{+/+}$mice on days 1 and 4 of pregnancy (Fig. 7b). Circulating corticosterone levels were significantly $(p=0.003)$ higher on day 1 compared with day 4 of pregnancy in both $R \ln ^{+/+}$and $R \ln ^{-/-}$mice (Fig. 7c) but there was no difference between the genotypes.

\section{Discussion}

The aims of this study were to confirm expression of relaxin and its receptor RXFP1 in the whole uterus of early pregnant mice prior to implantation and examine the effects of relaxin deficiency on endometrial angiogenesis and the expression of key angiogenesis-related and extracellular matrix remodeling genes in the pre-implantation period. Because fetal growth is compromised in $\mathrm{Rln}^{-1-}$ mice, and relaxin is thought to play a role in vascular growth in the endometrium in primates, our prediction was that pre-implantation angiogenesis in the endometrium would be compromised in $\mathrm{Rln}^{-1-}$ mice. In fact, we observed that blood vessel proliferation was not different in $\mathrm{Rln}^{-1-}$ mice compared to wild types before implantation. Unexpectedly, this was despite a general increase in the expression of many angiogenesis-related and other remodeling genes in the uteri of $\operatorname{Rln}^{-1-}$ mice compared to wild type animals, particularly on day 1 of pregnancy. Relaxin deficiency was also associated with an increase in circulating progesterone levels and progesterone receptor mRNA expression. Overall, our data demonstrate phenotypic changes in the pre-implantation uterus of $R l n^{-/-}$mice that include enhanced expression of steroid receptors, angiogenesis and matrix remodeling-related genes, but without the predicted impact on endometrial angiogenesis.

Circulating relaxin is undetectable in mice in early pregnancy [35] but relaxin gene transcripts were detected in the ovaries and uterus from day 1 of pregnancy. The surprising finding was the high expression of relaxin on day 3 of pregnancy for which we have no explanation. Previous studies have shown relaxin gene expression in the uterus of early pregnant pigs [36] and in HES cells in culture [21]. These data provide good evidence that relaxin is locally produced and can act in a paracrine fashion in the uterus. It was also important to demonstrate $R x f p 1$ expression in the uterus of mice in early pregnancy. $R x f p 1$ increased between days 1 and 4 of pregnancy in both $R l^{+/+}$and $\mathrm{Rln}^{-1-}$ mice. In fact, $R \times f p 1$ was higher in $R l^{-1-}$ mice at the start of pregnancy. Increased $R x f p 1$ expression has also been shown in the cervix and vagina of $\mathrm{Rln}^{-1-}$ mice [37] but not in the myometrium in late pregnancy [38]. This suggests differential 

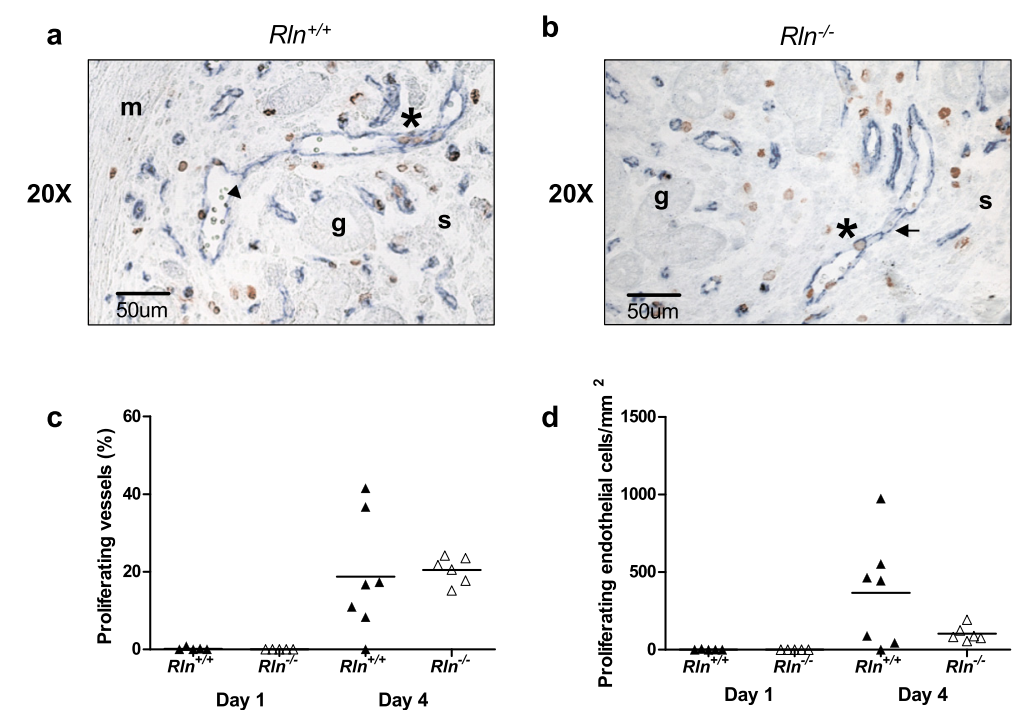

Fig. 6 Representative photomicrograph of CD31 (blue, pan-endothelial cell marker) and BrdU (brown, proliferating cell marker) immunostaining in the endometrium of a (a) wild type $\left(R / n^{+/+}\right)$and $(\mathbf{b})$ relaxin deficient $\left(R / n^{-1}\right)$ mice on day 4 of pregnancy. Black arrow indicates blood vessel profile; * = proliferating endothelial cell $s ; g=$ gland; $s=$ stroma; $m=$ myometrium. $\mathbf{c}$ Percentage of vessel profiles containing proliferating endothelial cells (\%) and the (d) number of proliferating endothelial cells per $\mathrm{mm}^{2}$ in the endometrium of $R / \mathrm{n}^{+/+}$and $R / \mathrm{n}^{-/-}$mice on days 1 and 4 of pregnancy $(n=5-7)$. Horizontal lines indicate mean values. Each triangle represents data from an individual mouse

regulatory effects of the relaxin ligand on its own receptors dependent on tissue and stage of pregnancy [39].

LacZ staining demonstrated that RXFP1 was localized predominantly in the inner circular layer of the myometrium, but also in the endometrial stroma similar to that shown by Kamat et al [26]. However, this observation was made in non-pregnant mice, so it is possible that the pattern of RXFP1 staining may differ in early pregnant mice, likely intensified in the endometrium. Several studies have reported high expression of immunoreactive RXFP1 in endometrial stromal cells in uterine samples from women during the menstrual cycle $[17,18]$ but this was not substantiated in later studies in which RXFP1 mRNA and relaxin binding sites were predominantly found in glandular and luminal epithelial cells [19]. No studies to date have assessed RXFP1 in early pregnancy in relation to angiogenesis. In women, there was an increase in RXFP1 in endometrial biopsies collected during the secretory phase relative to those from the proliferative phase [19]. It was not established if changes in RXFP1 occurred in stromal, epithelial or endothelial cells within the endometrium. However, Kohsaka et al [40] identified relaxin binding sites in epithelial cells, smooth muscle cells, and blood vessels in the cervix, vagina and uterus in tissues obtained from women after hysterectomy. RXFP1 has been localized specifically to endothelial cells $[41,42]$ in systemic and uterine blood vessels, but it remains to be demonstrated if relaxin receptors are expressed in endometrial endothelial cells in early pregnancy.
Because HES cells have previously been shown to express high affinity relaxin binding sites [15] and to secrete cAMP [27] and VEGF [15] in response to relaxin, these cells were used to screen for other potentially relevant genes upregulated by relaxin. Our microarray analysis of gene transcripts altered by relaxin in HES cells revealed a number of genes whose expression is associated with stimulation of angiogenesis, including Timp3, Hgf, and Hifia. These and other genes known to modulate steroid responsiveness, angiogenesis and extracellular remodeling, including Esr1, VegfA, Vegfr2, Pgr, Elgn1, Mmp14 and Ankrd37, were investigated in the mouse uterus by quantitative analysis. Genes including Esr1, Hgf, Hifla, Timp3, VegfA, Vegfr2 and Pgr were all upregulated by day 4 of pregnancy in the uterus of $\mathrm{Rln}^{+/+}$ mice relative to day 1 . This correlates well with previously published data [34, 43-46]. In addition, two other novel genes were upregulated in the uterus of early pregnancy, Egln1 and Mmp14. The latter remodels the ECM by activating other MMPs including MMP2 [47].

Fewer genes were analyzed in the in vivo study in mice; surprisingly, there was a significant increase in most of the genes examined on day 1 of pregnancy in the $R n^{-/}$mice. Most notably, there was a large increase in Pgr and Esr1, but not Esr2, as well as an increase in circulating progesterone on day 4 . This contrasts with previous work that demonstrated increases in Esr2, but not $E s r 1$, in the cervix and vagina of late pregnant $\mathrm{Rln}^{-/-}$ mice [37]. These differences may simply be due to tissue-specific expression or because we investigated the 


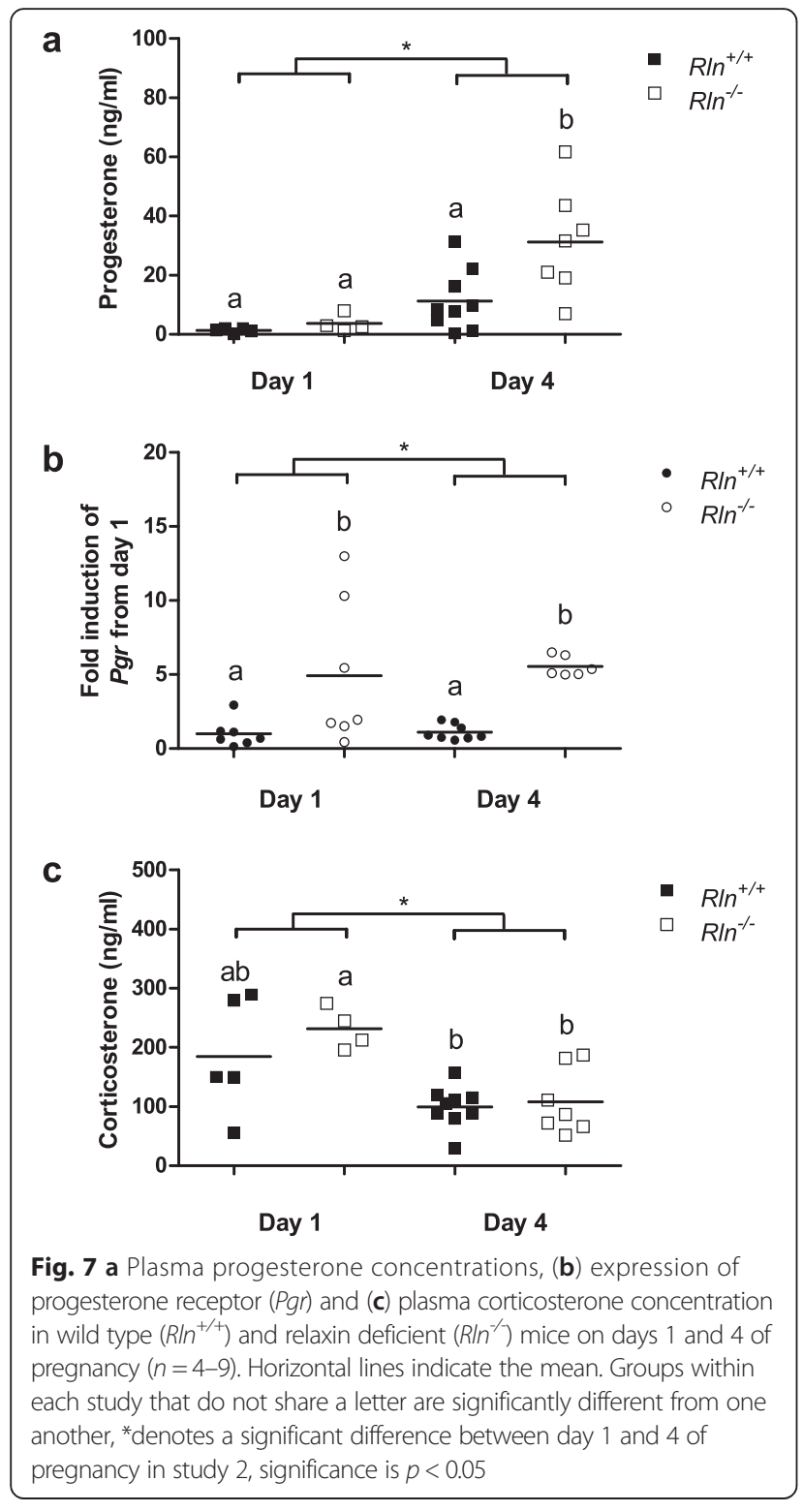

uterus prior to implantation, a time when the steroid hormone profile is very different to that later in pregnancy. Treatment of ovariectomized rhesus monkeys with relaxin reduces endometrial progesterone receptor isoforms $\mathrm{A}$ and $\mathrm{B}$, and $\mathrm{ER} \alpha$, without effecting ER $\beta$ [9]. These data support our findings in the $\mathrm{Rln}^{-1-}$ mice, and indicate a role for endogenous relaxin in the regulation of these receptors. Additionally, this accelerated increase in $P g r$ in the $R^{-1} n^{--}$mice could indirectly mediate the increased expression of the angiogenesis and extracellular matrix remodeling related genes on day 1 of pregnancy; further, we suggest that increased plasma progesterone levels, with increased expression of progesterone receptors, may be sufficient to compensate for the lack of relaxin in the stimulation of angiogenesis.
Another surprising finding was the increased VegfA expression in $\mathrm{Rln}^{-1-}$ mice on day 1 of pregnancy. Relaxin stimulates expression and secretion of VEGF in human endometrial stromal and glandular epithelial cells in a dose-dependent manner in vitro $[15,21]$. Therefore, we had predicted that in the absence of relaxin in early pregnancy, VegfA would be compromised. However, progesterone mediates its angiogenic effects partly through VEGF so the enhanced progesterone/Pgr expression on day 1 of pregnancy in $\mathrm{Rln}^{--}$mice could explain the increase in VegfA expression.

Similarly, given the rhRLX-induced increase in $H g f$ and Hifl $\alpha$ in the human microarray study, we anticipated that expression of these genes would be decreased in the uterus of the $\mathrm{Rln}^{-/-}$mice. This was not the case. The significance of the increased expression of VegfA, Esr1, Egln1, Hif1a, Mmp14 and Ankrd37 in the Rln ${ }^{-/}$ mice on day 1 of pregnancy is unknown. One possibility is that in the absence of relaxin, the estrous cycle is modified, with a shorter follicular phase and more rapid onset of estrus. Although our mice were synchronized around estrus, they could mate any time between $4 \mathrm{pm}$ and $8 \mathrm{am}$ when they were first checked for mating plugs. If the $\mathrm{Rln}^{-1-}$ mice had shorter estrous cycles, they could mate up to $12 \mathrm{~h}$ before $\mathrm{Rln}^{+/+}$mice, and therefore postcoital stimuli that trigger changes in the uterine environment would be accelerated in $\mathrm{Rln}^{-/-}$mice. Of interest, circulating corticosterone levels were significantly elevated in both genotypes on day 1 of pregnancy relative to day 4 , suggesting a possible stress response to mating and/or human contact post-coitus.

There are two noteworthy limitations in our study. First, our gene analysis used the whole uterus because it was not possible to separate the endometrium from the myometrium in the mouse uterus in early pregnancy and yield sufficient quantities of high quality RNA. We acknowledge that the homogenized uteri contain both endometrium and myometrium, and that there are spatiotemporal differences in the genes analyzed. Thus it is possible that relaxin deficiency could affect spatiotemporal gene expression. This could only be assessed through in situ hybridization. Second, we used HES cells in the microarray analysis to identify genes targeted by relaxin. Patterns of relaxin secretion vary in humans and rodents, with relaxin peaking in the first trimester in humans [48] and increasing throughout pregnancy in rodents [35, 49]. Furthermore, endometrial angiogenesis occurs in women before the arrival of the blastocyst and primarily occurs in mice after implantation. Therefore the role of relaxin in these two species could be quite different, and the preimplantation uterus may not be a substantial relaxin target in mice. Importantly, we would argue that relaxin-deficient mice are not an appropriate animal 
model to further investigate the role of relaxin in the pre-implantation uterus in humans.

\section{Conclusion}

In conclusion, we have demonstrated that relaxin deficiency in mice results in phenotypic changes in the pre-implantation uterus including differential expression of steroid receptor and angiogenesis/remodeling related genes and increased circulating progesterone. Consistent with previously published data, there was an increase in endometrial endothelial cell proliferation by day 4 of pregnancy in the $R \ln ^{+/+}$mice [6]; this was also seen in the $\mathrm{Rln}^{-1-}$ mice. However, there was no significant decrease in endometrial angiogenesis in the relaxin deficient mice. Nor was there accelerated blood vessel proliferation on day 1 of pregnancy in $R l n^{-/}$ mice despite the increased expression of angiogenesisrelated genes. Therefore, we conclude that endogenous relaxin does not play a major role in pre-implantation angiogenesis in the mouse uterus.

\section{Additional files}

Additional file 1: Figure S1. Expression of (a) Rxfp 1, (b) $\| 1 \beta$, (c) VegfA total, (d) Vegfr2, (e) Esr1, (f) Esr2, (g) Mmp14 and (h) Timp3 in the uterus of $R / n^{+/+}$and $R / n^{-1-}$ mice on day 6 of pregnancy (Study 3, $n=6-7$ ).

Horizontal bars indicate mean values. (PDF $35 \mathrm{~kb}$ )

Additional file 2: Figure S2. Expression of (a) $18 \mathrm{~s}$, (b) PpiA, (c) Sdha and (d) Tbp in the uterus of $\mathrm{R} \mathrm{n}^{+/+}$mice on days 1 to 4 of pregnancy $(n=6-8)$. Horizontal bars indicate mean values. Groups that do not share a letter are significantly different from one another $(p<0.05)$. (PDF $37 \mathrm{~kb})$

Additional file 3: Table S1. Primer and probe sequences for the quantitative amplification of murine genes. Table S2. Mean $C_{T}$ values and the range of $C_{T}$ values for each gene analyzed by GPCR in the uterus of wildtype $\left(R / n^{+/+}\right)$and relaxin deficient $\left(R / n^{-1}\right)$ mice $(n=6-8)$. Table S3. Primer sequences for the RT-PCR amplification of murine genes. (DOC $111 \mathrm{~kb}$ )

\section{Abbreviations}

Ankrd37: Ankryn repeat domain 37 gene; Egln1: E gl-9 family hypoxia-inducible factor 1 gene; ERa: Estrogen receptor alpha gene; ERß: Estrogen receptor beta gene; HES: Normal human endometrial stromal cells; Hgf: Hepatocyte growth factor gene; Hifla: Hypoxia inducible factor 1 alpha gene; II $\beta$ : Interleukin 1 beta gene; Mmp 14: Matrix metalloproteinase 14 gene; Pgr: Progesterone receptor gene; rhRLX: Recombinant human relaxin; RIn: Relaxin gene; $R / n^{-1}$ : Relaxin deficient mice; $R / n^{+/+}$: Wild type mice; $R \times f p 1$ : Relaxin receptor gene; Timp3: Tissue inhibitor of metalloproteinase 3 gene; VegfA: Vascular endothelial growth factor A gene; Vegfr2: VEGF Receptor 2 gene.

\section{Competing interests}

The authors declare that they have no competing interests.

\section{Authors' contributions}

SM carried out the uterine gene analysis, immunohistochemistry, performed the statistical analysis and wrote the manuscript. LN completed the reverse transcriptase study. ENU carried out the gene array study and drafted the manuscript. LJP carried out the RXFP1 localization study. LJP and JEG conceived the study, participated in its design and coordination and the drafting of the manuscript. All authors approved the final manuscript.

\section{Acknowledgements}

We thank Ms Tania Long and Mr Darren Cipolla for assisting in the maintenance of the mouse colony used in this study. We also thank Prof
Alexander Agoulnik (Florida International University, USA) for providing uterine tissues from non-pregnant transgenic mice with a modified Rxfp 1 gene.

\section{Author details}

${ }^{1}$ School of BioSciences, The University of Melbourne, Royal Parade, Parkville, Victoria, Australia. ${ }^{2}$ Corthera Inc., San Mateo, California, USA. ${ }^{3}$ Gynaecology Research Centre, Department of Obstetrics and Gynecology, The University of Melbourne and Royal Women's Hospital, Parkville, Victoria, Australia.

Received: 11 January 2016 Accepted: 14 March 2016

Published online: 22 March 2016

\section{References}

1. Demir R, Yaba A, Huppertz B. Vasculogenesis and angiogenesis in the endometrium during menstrual cycle and implantation. Acta Histochem. 2010;112(3):203-14.

2. Girling JE, Rogers PAW. Regulation of endometrial vascular remodelling: role of the vascular endothelial growth factor family and the angiopoietin-TIE signalling system. Reproduction. 2009;138(6):883-93.

3. Ball E, Bulmer JN, Ayis S, Lyall F, Robson SC. Late sporadic miscarriage is associated with abnormalities in spiral artery transformation and trophoblast invasion. J Pathol. 2006;208(4):535-42.

4. Aardema MW, Oosterhof H, Timmer A, van Rooy I, Aarnoudse JG. Uterine artery Doppler flow and uteroplacental vascular pathology in normal pregnancies and pregnancies complicated by pre-eclampsia and small for gestational age fetuses. Placenta. 2001;22(5):405-11.

5. Girling JE, Rogers PAW. Recent advances in endometrial angiogenesis research. Angiogenesis. 2005;8(2):89-99.

6. Walter LM, Rogers PAW, Girling JE. The role of progesterone in endometrial angiogenesis in pregnant and ovariectomised mice. Reproduction. 2005;129(6):765-77.

7. Parry $\amalg$, Vodstrcil LA. Relaxin physiology in the female reproductive tract during pregnancy. Adv Exp Med Biol. 2007;612:34-48.

8. Bryant-Greenwood GD, Rutanen E-M, Partanen S, Coelho TK, Yamamoto SY. Sequential appearance of relaxin, prolactin and IGFBP-1 during growth and differentiation of the human endometrium. Mol Cell Endocrinol. 1993;95(1-2):23-9.

9. Goldsmith LT, Weiss G, Palejwala S, Plant TM, Wojtczuk A, Lambert WC, et al. Relaxin regulation of endometrial structure and function in the rhesus monkey. Proc Natl Acad Sci U S A. 2004;101(13):4685-9.

10. Dallenbach-Hellweg G, Dawson AB, Hisaw FL. The effect of relaxin on the endometrium of monkeys histological and histochemical studies. J Anat. 1966;119(1):61-77.

11. Hisaw FL, Hisaw Jr FL, Dawson AB. Effects of relaxin on the endothelium of endometrial blood vessels in monkeys (Macaca mulatta). Endocrinology. 1967;81(2):375-85

12. Vasilenko P, Mead JP, Weidmann JE. Uterine growth-promoting effects of relaxin: a morphometric and histological analysis. Biol Reprod. 1986:35(4):987-95.

13. Einspanier A, Lieder K, Husen B, Ebert K, Lier S, Einspanier R, et al. Relaxin supports implantation and early pregnancy in the marmoset monkey. Ann N Y Acad Sci. 2009;1160:140-6.

14. Hayes ES, Curnow EC, Trounson AO, Danielson LA, Unemori EN Implantation and pregnancy following in vitro fertilization and the effect of recombinant human relaxin administration in macaca fascicularis. Biol Reprod. 2004;71(5):1591-7.

15. Unemori EN, Erikson ME, Rocco SE, Sutherland KM, Parsell DA, Mak J, et al. Relaxin stimulates expression of vascular endothelial growth factor in normal human endometrial cells in vitro and is associated with menometrorrhagia in women. Hum Reprod. 1999;14(3):800-6.

16. Seibold JR, Korn JH, Simms R, Clements PJ, Moreland LW, Mayes MD, et al. Recombinant human relaxin in the treatment of scleroderma. A randomized, double-blind, placebo-controlled trial. Ann Intern Med. 2000;132(11):871-9.

17. Ivell R, Balvers M, Pohnke $Y$, Telgmann R, Bartsch O, Milde-Langosch $K$, et al. Immunoexpression of the relaxin receptor LGR7 in breast and uterine tissues of humans and primates. Reprod Biol Endocrinol. 2003;1:114.

18. Luna JJ, Riesewijk A, Horcajadas JA, van Os R, Domínquez F, Mosselman S, et al. Gene expression pattern and immunoreactive protein localization of 
LGR7 receptor in human endometrium throughout the menstrual cycle. Mol Hum Reprod. 2004;10(2):85-90.

19. Bond $C P$, Parry $L$, Samuel $C S$, Gehring HM, Lederman FL, Rogers PAW, et al. Increased expression of the relaxin receptor (LGR7) in human endometrium during the secretory phase of the menstrual cycle. Ann N Y Acad Sci. 2005;1041(1):136-43.

20. Mazella J, Tang M, Tseng L. Disparate effects of relaxin and TGF $\beta 1$ : relaxin increases, but TGF $\beta 1$ inhibits, the relaxin receptor and the production of IGFBP-1 in human endometrial stromal/decidual cells. Hum Reprod. 2004;19(7):1513-8.

21. Palejwala S, Tseng L, Wojtczuk A, Weiss G, Goldsmith LT. Relaxin gene and protein expression and its regulation of procollagenase and vascular endothelial growth factor in human endometrial cells. Biol Reprod. 2002;66(6):1743-8.

22. Pillai $S B$, Rockwell LC, Sherwood OD, Koos RD. Relaxin stimulates uterine edema via activation of estrogen receptors: blockade of its effects using ICI 182,780, a specific estrogen receptor antagonist. Endocrinology. 1999;140(5):2426-9.

23. Parry L, Vodstrcil LA, Madden A, Amir SH, Baldwin K, Wlodek ME, et al. Normal mammary gland growth and lactation capacity in pregnant relaxin-deficient mice. Reprod Fertil Dev. 2009:21(4):549-60.

24. Gooi JH, Richardson ML, Jelinic M, Girling JE, Wlodek ME, Tare M, et al. Enhanced uterine artery stiffness in aged pregnant relaxin mutant mice is reversed with exogenous relaxin treatment. Biol Reprod. 2013;89(1):1-11.

25. Zhao L, Roche PJ, Gunnersen JM, Hammond VE, Tregear GW, Wintour EM, et al. Mice without a functional relaxin gene are unable to deliver milk to their pups. Endocrinology. 1999;140(1):445-53.

26. Kamat AA, Feng S, Bogatcheva NV, Truong A, Bishop CE, Agoulnik Al. Genetic targeting of relaxin and insulin-like factor 3 receptors in mice. Endocrinology. 2004;145(10):4712-20.

27. Fei DTW, Gross MC, Lofgren JL, Mora-Worms M, Chen AB. Cyclic AMP response to recombinant human relaxin by cultured human endometrial cells - A specific and high throughput in vitro bioassay. Biochem Biophys Res Commun. 1990;170(1):214-22.

28. Schena M, Shalon D, Heller R, Chai A, Brown PO, Davis RW. Parallel human genome analysis: microarray-based expression monitoring of 1000 genes. Proc Natl Acad Sci U S A. 1996;93(20):10614-9.

29. Yue H, Eastman PS, Wang BB, Minor J, Doctolero MH, Nuttall Rachel L, et al. An evaluation of the performance of CDNA microarrays for detecting changes in global mRNA expression. Nucleic Acids Res. 2001;29(8):e41.

30. Craythorn RG, Girling JE, Hedger MP, Rogers PAW, Winnall WR. An RNA spiking method demonstrates that $18 \mathrm{~S}$ rRNA is regulated by progesterone in the mouse uterus. Mol Hum Reprod. 2009;15(11):757-61.

31. Durrer S, Maerkel K, Schlumpf M, Lichtensteiger W. Estrogen target gene regulation and coactivator expression in rat uterus after developmental exposure to the ultraviolet filter 4-methylbenzylidene camphor. Endocrinology. 2005;146(5):2130-9.

32. Craythorn RG, Winnall WR, Lederman F, Gold EJ, O'Connor AE, de Kretser DM, et al. Progesterone stimulates expression of follistatin splice variants Fst288 and Fst315 in the mouse uterus. Reprod Biomed Online. 2012;24(3):364-74.

33. Dawson DW, Pearce SFA, Zhong R, Silverstein RL, Frazier WA, Bouck NP. CD36 mediates the in vitro inhibitory effects of thrombospondin-1 on endothelial cells. J Cell Biol. 1997;138(3):707-17.

34. Chakraborty I, Das SK, Dey SK. Differential expression of vascular endothelial growth factor and its receptor mRNAs in the mouse uterus around the time of implantation. J Endocrinol. 1995;147(2):339-52.

35. Ng SP, Steinetz BG, Lasano SG, Zelikoff JT. Hormonal changes accompanying cigarette smoke-induced preterm births in a mouse model. Exp Biol Med. 2006;231 (8):1403-9.

36. Bagnell CA, Zhang Q, Downey B, Ainsworth L. Sources and biological actions of relaxin in pigs. J Reprod Fertil Suppl. 1993;48:127-38.

37. Parry $\amalg$, McGuane JT, Gehring HM, Kostic IGT, Siebela AL. Mechanisms of relaxin action in the reproductive tract: studies in the relaxin-deficient (Rlx-/-) mouse. Ann N Y Acad Sci. 2005;1041(1):91-103.

38. Siebel AL, Gehring HM, Reytomas IGT, Parry LJ. Inhibition of oxytocin receptor and estrogen receptor-a expression, but not relaxin receptors (LGR7), in the myometrium of late pregnant relaxin gene knockout mice. Endocrinology. 2003;144(10):4272-5.

39. Vodstrcil LA, Shynlova O, Verlander JW, Wlodek ME, Parry LJ. Decreased expression of the rat myometrial relaxin receptor (RXFP1) in late pregnancy is partially mediated by the presence of the conceptus. Biol Reprod. 2010;83(5):818-24.

40. Kohsaka T, Min G, Lukas G, Trupin S, Campbell ET, Sherwood OD. Identification of specific relaxin-binding cells in the human female. Biol Reprod. 1998;59(4):991-9.

41. Jelinic M, Leo C-H, Uiterweer EDP, Sandow SL, Gooi JH, Wlodek ME, et al. Localization of relaxin receptors in arteries and veins, and region-specific increases in compliance and bradykinin-mediated relaxation after in vivo serelaxin treatment. FASEB J. 2014;28(1):275-87.

42. Vodstrcil LA, Tare M, Novak J, Dragomir N, Ramirez RJ, Wlodek ME, et al. Relaxin mediates uterine artery compliance during pregnancy and increases uterine blood flow. FASEB J. 2012;26(10):4035-44.

43. Tan J, Paria BC, Dey SK, Das SK. Differential uterine expression of estrogen and progesterone receptors correlates with uterine preparation for implantation and decidualization in the mouse. Endocrinology. 1999;140(11):5310-21.

44. Walter LM, Rogers PAW, Girling JE. Differential expression of vascular endothelial growth factor-A isoforms in the mouse uterus during early pregnancy. Reprod Biomed Online. 2010;21(6):803-11.

45. Das SK, Yano S, Wang J, Edwards DR, Nagase H, Dey SK. Expression of matrix metalloproteinases and tissue inhibitors of metalloproteinases in the mouse uterus during the peri-implantation period. Dev Genet. 1997;21(1):44-54.

46. Daikoku T, Matsumoto H, Gupta RA, Das SK, Gassmann M, DuBois RN, et al. Expression of hypoxia-inducible factors in the peri-implantation mouse uterus is regulated in a cell-specific and ovarian steroid hormone-dependent manner: evidence for differential function of HIFs during early pregnancy. J Biol Chem. 2003;278(9):7683-91.

47. Sato H, Takino T, Okada Y, Cao J, Shinagawa A, Yamamoto E, et al. A matrix metalloproteinase expressed on the surface of invasive tumour cells. Nature. 1994;370(6484):61-5.

48. Bell RJ, Eddie LW, Lester AR, Wood EC, Johnston PD, Niall HD. Relaxin in human pregnancy serum measured with an homologous radioimmunoassay. Obstet Gynecol. 1987;69(4):585-9.

49. Sherwood OD, Crnekovic VE, Gordon WL, Rutherford JE. Radioimmunoassay of relaxin throughout pregnancy and during parturition in the rat. Endocrinology. 1980;107(3):691-8.

\section{Submit your next manuscript to BioMed Central and we will help you at every step:}

- We accept pre-submission inquiries

- Our selector tool helps you to find the most relevant journal

- We provide round the clock customer support

- Convenient online submission

- Thorough peer review

- Inclusion in PubMed and all major indexing services

- Maximum visibility for your research

Submit your manuscript at www.biomedcentral.com/submit
) Biomed Central 